\title{
CORRESPONDENCE
}

\section{METAMORPHIC SEGREGATION BODIES}

SIR,-Structures similar to those described by Miss Knill (1959) have been reported from enclaves of metasediment in the South Savannas Granite of British Guiana (Barron, 1959). They show some additional points of interest and are briefly reviewed below.

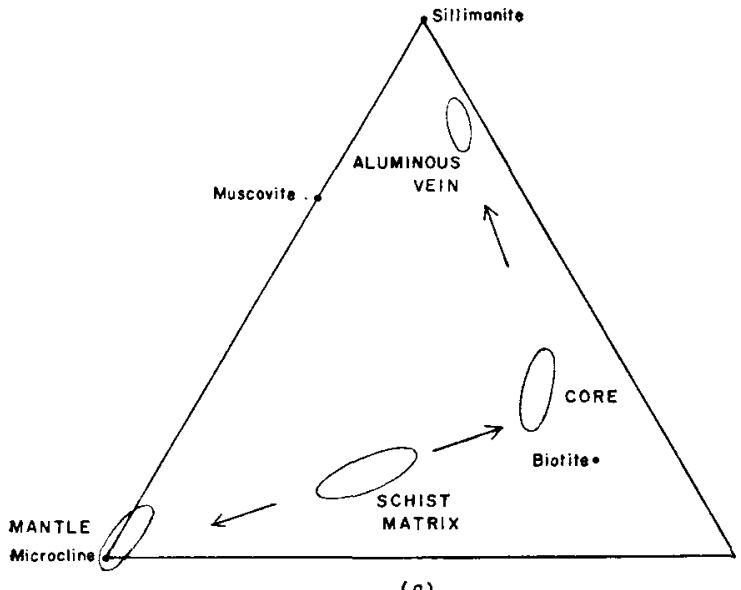

(a)

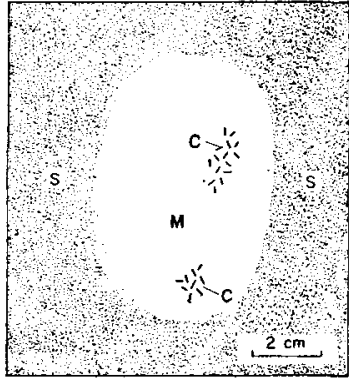

(b)

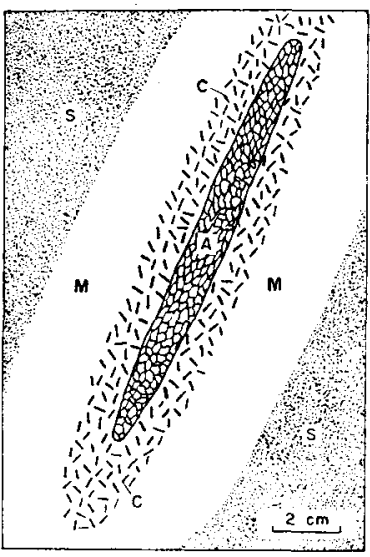

(c)

$\mathbf{S}=$ schist matrix

$\mathrm{M}=$ potassium-rich mantle.

$\mathrm{C}=$ core

$\mathrm{A}=$ axial vein.

TEXT-FIG. 1

(a). AKF diagram showing differentiation trends.

(b). Normal segregation body in schist.

(c). Lenticular segregation in schist, with aluminium rich axial vein. 
The structures occur in quartz-microcline-oligoclase-biotite schist, within a half-mile of the very extensive South Savanna biotite granite. In some of the more biotite-rich enclaves they closely resemble Miss Knill's examples both in size and in the relative proportions of core and mantle, but cordierite is absent while sillimanite in the mantle is accompanied by andalusite idiomorphs. Usually, however, the structures are larger-up to $10 \mathrm{cms}$. acrosswhile the cores measure only one or two cms. in the largest examples. Quartz, plagioclase and iron oxide occur throughout core and mantle, and in the surrounding schist. In addition to these minerals the core usually carries coarse green-brown biotite and cordierite which is commonly poiciloblastic and appears to have replaced most of the original constituents of the rock. The mantle carries, on the contrary, no biotite, but abundant fresh microcline, which has usually induced an albite-enriched rim in the plagioclase in contact with it. In addition, muscovite, together with small granules of new quartz, appears to have been derived largely from the microcline in mantle and unaltered schist. The biotite of matrix and core is identical, and appears to have recrystallized last of all. Sillimanite is sometimes present, but in the core rather than in the mantle.

Nearer the granite, more aluminous segregations develop, at first as clots carrying quartz, cordierite, and sillimanite, and associated with the cores described above. These finally develop into lenticles carrying coarse quartz along the axis, with 10 to 15 per cent of sillimanite together with some cordierite and plagioclase. The margin carries the usual clot minerals-quartz, biotite, plagioclase with minor sillimanite, muscovite-and in addition some green chlorite.

The accompanying sketches and AKF diagram show the form of the structures and summarize the mineralogical trends involved in the differentiation into core and mantle, and in the later development of alumina-rich veins. There appears to have been no volume change, at least in the former, so that an overall access of potassium must follow from the small relative size of the core. The development of the veins likewise indicates an access of aluminium from outside the system.

I should like to thank Professor Deer for his kindness in enabling me to use laboratory and X-ray facilities in connection with the structures described.

\title{
REFERENCES
}

Barron, C. N., 1959. Some features of interest in the South Rupununi Savannas. Proc. Vth Inter-Guiana Geol. Conf. Georgetown (in Press). KNILL, D. C., 1959. Metamorphic Segregation Structures from Rossguill, Eire. Geol. Mag., xcvi, 374-376.

\author{
Geological Survey Department, \\ BRICKDAM, \\ GeORGETOWN, \\ British Guiana.
}

I6th January, 1960.

\section{N. BARron.}

\section{IRISH EROSION SURFACES}

SIR,-In the course of his study of altimetric frequency graphs, Mr. G. L. Davies (1958) has drawn attention to the similarities in the graphs, based on 20-foot groupings, for ten of the southern counties (Dublin, Wicklow, Wexford, Tipperary, Waterford, Cork, Kerry, Limerick, Clare and Galway) and the similarities in the graphs for ten of the northern counties of Ireland (Mayo, Sligo, Leitrim, Donegal, Tyrone, Londonderry, Antrim, Down, 